\title{
Açıklama Destekli REACT Stratejisi ile İlgili Öğretmen Adaylarının Görüşleri*
}

\section{Teacher Candidates' Opinions about the Explanation- Assisted REACT Strategy}

\author{
Eser ÜLTAY**, Nedim ALEV***
}

\begin{abstract}
Öz: Bu araştırmanın temel amacı, fen bilgisi öğretmen adaylarının açıklama destekli REACT stratejisinin fizik öğretiminde kullanılması hakkındaki düşüncelerini incelemektir. Araştırmada örnek olay yöntemi kullanılmıştır. Araştırmanın örneklemini, gönüllü, 25 öğretmen adayı oluşturmaktadır. Bu araştırmada veri toplama aracı olarak açık uçlu sorular içeren tarama formu kullanılmıştır. Tarama formundaki sorulara katılımcıların verdikleri cevaplar indirgemeler yapıldıktan sonra kritik cevaplar tespit edilmiștir. Ardından farklı zamanlarda, bu kritik cevaplara uygun kodlar belirlenmiş ve kod listesi oluşturulmuştur. Belirlenen bu kodlara göre, temalar oluşturulmuş ve kodlar uygun temaların altında sergilenmiștir. Öğretmen adaylarının, strateji hakkındaki düşünceleri altı tema altında toplanmıştır. Bu temalar, "Öğrenme", "Sunum", "Gerçek Hayat", "Endișe ve Sıkıntı", "Öneri” ve "Ders Materyalleri” şeklindedir. Katılımcılar açıklama destekli REACT stratejisi ile öğrenmeyi daha çok stratejinin öğrenme üzerindeki kalıcılığı ile ilişkilendirmişlerdir. Bununla beraber açıklama destekli REACT stratejisinin anlaşılır, zevkli, ilgi çekici ve kolay olmasının yanı sıra iş birlikli öğrenmeyi sağladığı için öğrenmeye pozitif etkileri olduğunu belirtmişlerdir. Açıklama destekli REACT stratejisi ile ilgili katılımcıların olumlu düşünceleri, daha uzun süreli yapılan araştırmalarda tutumun da değişebileceğini düşündürmektedir. Bu bağlamda, açıklama destekli REACT stratejisinin kullanıldığı daha uzun süreli araştırmalarda fizik dersine karşı olan tutum da araştırılabilir.
\end{abstract}

Anahtar Kelimeler: Açıklama destekli REACT stratejisi, itme-momentum ve çarpışmalar, öğretmen adayı görüşleri

Abstract: The main purpose of this study was to examine the opinions of the science teacher candidates about the usage of explanation-assisted REACT strategy in physics teaching. Case study method was used in the study. The study was carried out with 25 volunteer science teacher candidates. In the study, a questionnaire consisting of open ended questions was used as a data collection tool. After reduction of the science teacher candidates' answers of the questionnaire, critical answers were determined. Then, at different times, the codes corresponding to these critical answers were determined and a code list was created. Based on these codes, the themes were created and the codes were displayed under the appropriate themes. The opinions of the science teacher candidates about the strategy are grouped under six themes. These themes were stated as "learning", "presentation", "real life", "anxiety and trouble","suggestion" and "course materials". The assosiciation of explanation-assisted REACT strategy to learning was mostly done about the permanency of the strategy on learning by the participants. However, they pointed out that the explanation-assisted REACT strategy had positive effects on learning because it provided cooperative learning besides being understandable, enjoyful, attractive and easy. Participants' positive thoughts on the explanation-assisted REACT strategy suggested that attitudes may change in longer-term studies. In this context, the attitude towards the physics course can also be investigated in longer studies using the explanation-assisted REACT strategy.

\footnotetext{
*Bu araştırma, birinci yazarın "İtme, momentum ve çarpışmalar konusuyla ilgili bağlam temelli öğrenme yaklaşımına dayalı açıklama destekli REACT stratejisine göre geliştirilen etkinliklerin etkisinin araştırılması" isimli doktora tezinin bir bölümüdür. Bu araştırmanın kısa özeti; 12. Ulusal Fen Bilimleri ve Matematik Eğitimi Kongresi, 28-30 Eylül 2016, Trabzon'da sunulmuştur.

**Yrd. Doç. Dr., Giresun Üniversitesi, Eğitim Fakültesi, Giresun-Türkiye, e-posta: eserultay@gmail.com

***Doç. Dr., Karadeniz Teknik Üniversitesi, Fatih Eğitim Fakültesi, Trabzon-Türkiye, e-posta: nedimalev@hotmail.com
} 
Keywords: Explanation-assisted REACT strategy, impulse-momentum and collisions, teacher candidates' opinions

\section{Giriş}

Yapılandırmacı öğrenme kuramında öğrenciler bilgiyi yaparak yaşayarak ve kendi zihinlerinde yapılandırarak bu bilgilerin günlük yaşamla ilişkisini kurabilirler (Aktamış, Ergin ve Akpınar, 2002; Colburn, 2000; Saka, 2006). Bilimsel okuryazar bireyler yetiştirmek ve fen eğitiminin en önemli amaçlarından birisi olan anlamlı ve kalıcı öğrenmeyi sağlamak için öğretim ortamlarında faydalanılan yapılandırmacı öğrenme kuramı, uygulandıkları öğrenme ortamlarında, öğrenci başarısında olumlu sonuçlar verse de (Özsevgeç, 2006; Van Hook ve Huziak-Clark, 2007) eğitim sistemindeki bazı temel sorunların varlığını sürdürdüğü görülmektedir. Ayrıca son yıllarda fen eğitimine verilen önemin artmasına karşl1ık, üniversitelerde fen bilimlerinin önemli bir branşı olan fiziği seçen öğrenci sayısında ciddi bir düşüş görülmektedir (Azuma ve Nogao, 2008; Sharma, 2004; Whitelegg, 1996; Yaman, Dervişoğlu ve Soran, 2004). Bu düşüşün ve çözümlenemeyen sorunların sebeplerini bulabilmek amacıyla fen/fizik eğitimindeki problemler tekrar tartışılmaya başlanmıştır. Bu problemlerden en önemlileri fizik dersinin günlük yaşamla yeteri kadar ilişkilendirilmemiş olması (Acar ve Yaman, 2011; Gilbert, 2006; Stolk, Bulte, de Jong ve Pilot, 2009a; Ültay, 2017; Wilkinson, 1999b), öğrencilerin "Bunu neden öğrenmem gerekiyor?" sorusuna cevap vermedeki yetersizlikleri (Demircioğlu, Demircioğlu ve Çalık, 2009; Gilbert, 2006; Stolk, Bulte, de Jong ve Pilot, 2009b; Ültay ve Çalık, 2012) ve öğrencileri bilimsel bilgileri ezberlemeye yönelten baskın bir geleneksel fen eğitiminin varlığıdır (Stolk ve diğerleri, 2009a).

Fen/fizik eğitiminde karşılaşılan bu ve benzeri problemleri gidermek ve eğitimin kalitesini artırmak için bağlam temelli öğrenme yaklaşımı eğitimde oldukça yaygın olarak kullanılmaya başlanmıştır. Öğrencilerin, yeni bilgilerle günlük yaşamlarındaki deneyimlerini ilişkilendirmede tanıdık bağlamlar kullanılmasını öngören bağlam temelli öğrenme yaklaşımı temelde yapılandırmacı öğrenme yaklaşımının üzerine inşa edilmiştir (Berns ve Erickson, 2001; Crawford, 2001; Glynn ve Koballa, 2005; Imel, 2000; Lynch ve Padilla, 2000). Bağlam temelli öğrenme yaklaşımında öğrencilerin fiziksel bilgilerin birbirini takip eden mantıklı zihinsel haritalarını oluşturabilmeleri için, bilimsel içerik, bilgiye ihtiyaç duydukları (need-to-know basis) bir bağlama dayandırılmalıdır. Bilgiye ihtiyaç duyulan bir ortamın yaratılması bağlam temelli öğrenme yaklaşımının temel taşıdır ve ayrıca öğretim açısından da oldukça anlamlıdır. Öğrencilerin bu ortamlarda yaparak yaşayarak öğrenmesi sağlandığı gibi öğrenme anlamlı ve kalıcı olur. Bu yolla bilgilerin birbirleriyle olan uyumu artacağı gibi (Pilot ve Bulte, 2006), öğrencilerin derse olan ilgi ve motivasyonları da artacaktır (Basir, Alinaghizadeh ve Mohammadpour, 2008; Rayner, 2005; Tekbıyık, 2010; Whitelegg ve Edwards, 2001; Wierstra, 1984).

Ancak ülkemizde son yıllarda kullanılmaya başlanan bağlam temelli öğrenme yaklaşımı Ayvacı (2010) ve Ayvacı, Ültay ve Mert'in (2013) araştırmalarında belirttiği gibi ülkemizdeki öğretmenler tarafından yeterince tanınmamaktadır. Öğretmenlerin bağlam temelli öğrenme yaklaşımıyla ilgili bilgilerinin yeterli düzeyde olmadığı göz önünde bulundurulduğunda, bu öğrenme yaklaşımının öğrenme ortamlarında kullanılması ve olumlu/olumsuz yönlerinin tartışılması önem taşımaktadır.

Bağlam temelli öğrenme yaklaşımının hedeflediği amaçları yerine getirebilmesi için öğrenme ortamlarında kullanılan stratejilerden birisi de REACT stratejisidir. İlk olarak CORD (Center for Occupational Research and Development) (1999a, 1999b), Souders (1999) ve Crawford'un (2001) tanıttıkları REACT stratejisinin ilkeleri Tablo 1'de açıklanmıştır.

Tablo 1

REACT Stratejisinin İlkeleri (CORD, 1999a, 1999b; Navarra, 2006)

\begin{tabular}{ll}
\hline Relating & Ön bilgi ve geçmiş tecrübelerle ilişki kurarak bilgiyi bağlamsallaştırma \\
Experiencing & Yaparak-yaşayarak, tecrübe ederek, keşfederek veya icat ederek ögrenme \\
Applying & Sınıf, laboratuvar gibi ortamlarda verileri uygulama ve kullanılacak \\
\hline
\end{tabular}




\begin{tabular}{ll}
\hline \multirow{2}{*}{ Cooperating } & kavramları ortaya koyarak öğrenme \\
Transferring & $\begin{array}{l}\text { Başkalarıyla bilgi paylaşımında bulunarak ve iletişim kurarak öğrenme } \\
\text { bilgiyi kullanma }\end{array}$ \\
\hline
\end{tabular}

Ültay (2013) ve Ültay ve Ültay’ın (2014) bağlam temelli öğrenme yaklaşımıyla ilgili yapmış oldukları içerik analizinde de belirttikleri gibi, bağlam temelli öğrenme yaklaşımının öğrenme ortamlarında uygulanabilmesi için REACT stratejisinin yanı sıra yeni modellere de ihtiyaç duyulmaktadır. Literatürdeki bazı araştırmalarda REACT stratejisinin uygulanması esnasında karşılaşılan problemlere ve REACT stratejisinin geliştirilmesi gerektiğine dikkat çekilmiştir (Coştu, 2009; E. Ültay, 2012; N. Ültay, 2012; Ültay, Durukan ve Ültay, 2014). Coştu (2009) yapmış olduğu araştırmanın REACT stratejisi ile ilgili sonuçları doğrultusunda, stratejide aksayan noktaların giderilmesi açısından açıklama ve tartışma ilkelerinin eklenerek bu konuda daha detaylı araştırmalar yapılması gerektiğini önermiştir. E. Ültay (2012) da araştırmasında REACT stratejisine bazı ilkelerin eklenmesi gerektiğine dikkati çekmiştir. N. Ültay (2012) da karşılaştığı problemler doğrultusunda açıklama ilkesinin de eklenmesi sonucu geliştirdiği REEACT (Relating - Experiencing - Explaining - Applying - Cooperating Transferring) stratejisini daha verimli bir öğretimin gerçekleşmesi için eğitim araştırmalarında kullanılması gerektiğini belirtmiştir. Ültay vd. (2014) ise araştırmalarında stratejiye açıklama ilkesinin ayrı bir ilke olarak eklenmesini veya REACT stratejisinin bütün ilkelerine açıklama kısımlarının eklenmesini önermişlerdir.

Açıklama yapmak öğrencilerin yetersiz olan ön düşüncelerini daha doğru olan yenileriyle değiştirmelerine yardımcı olur. Çünkü öğrenciler çoğu zaman öğretmenin yardımı olmadan yeni düşünme yollarını bulmakta güçlük çekerler (Özmen, 2002). Bu sebeple öğretmenin öğrencilerin deneyimlerini bir araya getirmelerinde, sonuçlarını açıklamalarında ve yeni kavramlar oluşturmalarında onlara temel bilgi düzeyinde açıklamalarda bulunarak yardımcı olması (Akdeniz ve Akbulut, 2010) öğrenmenin daha anlamlı olmasına yardımcı olur. Bu anlamda eğitim öğretim esnasında özellikle açıklama ilkesinin eksikliğinin yaşandığı REACT stratejisinin genişletilmiş versiyonu olan açıklama destekli REACT stratejisinin öğretim ortamlarında denenmesi, bu yeni modelin olumlu ve olumsuz yönlerinin tartışılması gerektiği düşünülmektedir. Bağlam temelli öğrenme yaklaşımının esas alındığ 1 fizik eğitimi araştırmaları göz önünde bulundurulduğunda itme, momentum ve çarpışmalar konusunun oldukça az çalışı1mış olması dikkati çekmektedir. Aslında itme, momentum ve çarpışmalar konusu öğrencilerin günlük yaşamlarından aşina oldukları bir konudur. Örneğin misket oyunu, trafik kazalarında araçların çarpışması, bilardo oyunu, silahların ateşlendikten sonra geri tepmesi ve havai fişek gösterileri öğrencilerin günlük hayatta sıkça karşılaştıkları olaylardandır.

Konuyla ilgili alternatif kavramlara sahip öğrenciler üniversiteye geldiklerinde, bu alternatif kavramları giderecek bir eğitimle karşılaşmak yerine soyut kavramların yapılanmasında, alternatif kavramları gidermede ve kavramsal değişimi sağlamada yetersiz olduğu kabul edilen daha çok sunuş yoluyla öğretime dayanan bir öğrenme ortamıla karşılaşmaktadırlar (Harrison ve Treagust, 2001; Hewson, 1992; Hewson ve Hewson, 2003). Bu durumda itme, momentum ve çarpışmalar konusunun etkili ve kalıcı öğrenilmesi de beklenemez. Günlük yaşamla ilişkili konular öğrencilere aktarılırken, öğrencilerin çevrelerindeki olaylar ve nesnelerle ne kadar ilişkilendirilirse, o kadar etkili ve kalıcı öğrenme sağlanır. Ayrıca öğrencilerin de ilgi ve motivasyonları canlı tutulmuş olur (Ay, 2008).

Sonuç olarak, geleneksel öğretim yaklaşımının tersine, bağlam temelli öğrenme yaklaşımı, öğrencileri konu içeriği yoğun bir programla baş başa bırakıp, bu konuların günlük yaşamla ilişkisini çok az yansıtmak yerine, öğrencilerin bilimsel bilgiye ihtiyaç duydukları bir ortamın oluşturulmasını hedefler. Bunu yaparken öğrencilerin ilgisini çekecek günlük yaşamla ilişkili bağlamlar kullanılması ve içeriğin bu bağlamlar üzerinden aktarılması öğretimin daha anlamlı ve kalıcı olmasına etki edebilir. Bununla beraber, itme, momentum ve çarpışmalar konusunda öğrencilerin veya öğretmen adaylarının çok sayıda alternatif kavrama sahip olması, bu konunun günlük yaşamla ilişkili bağlamlar dahilinde öğretilmesini ve yapılmış bazı 
araştırmalarda önerildiği gibi mevcut REACT stratejisinin açıklama ilkesiyle genişletilmiş versiyonu olan açıklama destekli REACT stratejisinin uygulanmasını önemli kılmaktadır.

Bağlam temelli öğrenme yaklaşımının öğrencilerin ilgi ve motivasyonlarına olan olumlu etkisi (Choi ve Song, 1996; Edwards, 2000; Finkelstein, 2005; Rayner, 2005; Tekbiy1k, 2010) göz önüne alındığında REACT stratejisinin de öğrenme ortamlarında benzer etkiyi göstermesi beklenirdi. Ancak N. Ültay (2012) araştırmasında REACT stratejisinin öğretmen adayları üzerinde beklenenin aksine ilgi ve motivasyonlarında bir değişiklik yaratmadığını bulmuştur. Halbuki bağlam temelli öğrenme yaklaşımının en önemli dayanak noktalarından biri tanıdık bağlamlar sayesinde öğrencilerin ilgi ve motivasyonlarını artırarak onları derse yönlendirmektir. Bu açıdan yaklaşıldığında açıklama destekli REACT stratejisinin de öğretmen adaylarının ilgileri üzerinde nasıl bir etkisinin olduğunu gözlemlemek, dersin öğretmen adayları üzerindeki etkisini ve onların bu yeni model hakkındaki bakış açılarını belirlemek açısından etkili olacaktır. Bunlardan yola çıkarak bu araştırmanın temel amacı, fen bilgisi öğretmen adaylarının açıklama destekli REACT stratejisinin fizik öğretiminde kullanılması hakkındaki düşüncelerini incelemektir.

\section{Araştırmanın Problemi}

$\mathrm{Bu}$ araştırmanın temel problemi, "Öğretmen adaylarının açıklama destekli REACT stratejisinin fizik öğretiminde kullanılması hakkındaki düşünceleri nelerdir?” şeklinde ifade edilebilir.

\section{Yöntem}

Araştırmada öğretmen adaylarının açıklama destekli REACT stratejisi hakkındaki düşünceleri belirlenmeye çalış1ldığından araştırma örnek olay yöntemine uygundur. Örnek olay yöntemi bir ya da daha fazla olayın, ortamın, programın, sosyal grubun ya da diğer birbirine bağlı sistemlerin derinlemesine incelendiği bir yöntemdir (Büyüköztürk, Kılıç Çakmak, Akgün, Karadeniz ve Demirel, 2012). Bu araştırmada ise bir grubun belirli bir konu hakkındaki düşüncelerini derinlemesine belirlemek amaciyla kullanılmıştır.

Bu araştırmanın örneklemini Giresun Üniversitesi Eğitim Fakültesi Fen Bilgisi Eğitimi Anabilim Dalında birinci sınıfta öğrenim görmekte olan 25 öğretmen adayları oluşturmaktadır.

\section{Veri Toplama Araçları}

$\mathrm{Bu}$ araştırmada veri toplama aracı olarak öğretmen adaylarının açıklama destekli REACT stratejisinin fizik öğretiminde kullanılması hakkındaki düşüncelerini belirlemek amacıyla tarama formu kullanılmıştır. İnsanların göstermiş oldukları davranışların, benimsedikleri görüşlerin veya bir olay hakkındaki fikirlerinin belirlenmesinde en önemli kaynak kişilerin kendi ifadeleridir. Bu ifadeler ise anketler aracılığıyla yazılı veya sözlü olarak elde edilebilir (Balc1, 2011). Anketlerde yer alan sorular birbirinden bağımsız olabileceği gibi öğrencilerin derse yönelik tutumları, öğretmenin sınıf yönetimi davranışları veya öğrenme stratejileri gibi özelliklerin ölçülmesi söz konusu olduğunda ilişkili olarak da yöneltilebilir (Büyüköztürk ve diğerleri, 2012). Kişisel özellikler, ilgiler, tutumlar gibi özellikleri ölçmek için geliştirilen araçlara envanter, anket, ölçek, test ve tarama gibi isimlerin kullanılabileceği belirtilmiştir (Aiken, 1997'den aktaran: Büyüköztürk ve diğerleri, 2012, s. 124).

Araştırmada kullanılan tarama formu dört açık uçlu temel sorudan oluşmaktadır. Sorulardan bir tanesi için, verilen cevaba göre ikinci bir sorusu daha mevcuttur. Tarama formu, öğretmen adaylarının öğrenme süreciyle ilgili, açıklama destekli REACT stratejisi hakkındaki, bütün olumlu ve/veya olumsuz görüşlerini net bir şekilde ifade edebilmeleri açısından dikkatle hazırlanmıştır.

Tarama formu soruları oluşturulduktan sonra dört alan eğitimi uzmanına inceletilerek görüşleri alınmıştır. Uzman görüşleri doğrultusunda bazı sorularda düzenlemeler yapılmıştır. Örneğin "İtme, Momentum ve Çarpışmalar konularının işlendiği derslerde kullanılan bu yöntemin en beğenmediğiniz kısımları nelerdir? Bu yöntemin beğenmediğiniz kısımları için ne tür bir değişiklik yapılmasını önerirdiniz? Detaylıca açıklayınız." sorusu iki kısma ayrılmış, ana soru olarak "İtme, Momentum ve Çarpışmalar konularının işlendiği derslerde kullanılan bu 
yöntemin en beğenmediğiniz kısımları nelerdir? Nedenleriyle açıklayınız.”, ikinci bir soru olarak da "Derslerde kullanılan bu yöntemin beğenmediğiniz kısımları için ne tür bir değişiklik yapılmasını önerirdiniz? Detaylıca açılayınız." soruları kullanılmıştır.

\section{Araştırma Süreci}

Araştırmada öğretmen adaylarının açıklama destekli REACT stratejisi hakkındaki düşüncelerini belirlemeden önce itme, momentum ve çarpışmalar konusu açıklama destekli REACT stratejisine uygun bir şekilde, bu araştırma için, 10 ders saatlik $(10 * 50$ dakika $=500$ dakika $)$ bir süre içerisinde Genel Fizik I ve Genel Fizik Laboratuvarı I dersleri kapsamında öğretilmiştir.

Açıklama destekli REACT stratejisine göre geliştirilen ders planları ve materyallerinde açıklama destekli REACT stratejisindeki bütün ilkeler döngüsel olarak takip edilmiş olup, ünitenin kazanımlarına göre iki ayrı ders planı hazırlanmıştır.

Açıklama destekli REACT stratejisine göre geliştirilen ders planlarına bağlı kalarak öğretim süresince kullanılacak ders materyalleri, araştırmacı ve bir fizik eğitimi uzmanı tarafından geliştirilmiştir. Uygulanan birinci ders planının aşamaları özet olarak Tablo 2'de verilmiştir.

Tablo 2

Uygulanan Birinci Ders Planı

\begin{tabular}{|c|c|c|}
\hline Aşama & Araştırmacının Rolü & Öğretmen Adaylarının Rolü \\
\hline $\begin{array}{l}\text { İlişkilendirme- } \\
\text { Açıklama- } \\
\text { İşbirliği }\end{array}$ & $\begin{array}{l}\text { Araştırmacı ögretmen adaylarından } \\
\text { "Buz Pisti" isimli okuma parçasında } \\
\text { geçen itme durumlarını bulmalarını } \\
\text { ister. Bu esnada herhangi bir } \\
\text { yönlendirme yapılmaz. } \\
\text { Öğretmen adayları kendilerine } \\
\text { gösterilen görsellerdeki itme ile ilgili } \\
\text { durumları ve nedenlerini bulmaya } \\
\text { çalışırken, onlara gerekli yerlerde } \\
\text { sorular sorarak tartısma ortamı } \\
\text { yaratır ve yönlendirmelerde bulunur. } \\
\text { Konunun ilgili bölümleri hakkında } \\
\text { açıklamalarda bulunur. } \\
\text { Araştırmacı öğretmen adaylarının } \\
\text { sunumlarını dikkatlice dinleyerek, } \\
\text { yanlış veya eksik noktalarda } \\
\text { yönlendirmelerde bulunur. }\end{array}$ & $\begin{array}{l}\text { Öğretmen adayları derse itme ve } \\
\text { momentum kavramlarını içeren "Buz } \\
\text { Pisti" isimli okuma parçasını } \\
\text { okuyarak başlarlar ve itme ile ilgili } \\
\text { durumları bulmaya çalışırlar. } \\
\text { Ardından kendilerine gösterilen } \\
\text { günlük yaşamdan alınmış görsellerin } \\
\text { hangilerinde itme olayının } \\
\text { gerçekleşip gerçekleşmediğini } \\
\text { belirtip bu durumların nedenlerini } \\
\text { gerekli alanlara yazarlar. } \\
\text { Öğretmen adayları gruplar halinde } \\
\text { itme ve momentumla ilgili grafikler } \\
\text { çizerek yorumlamaya çalışırlar. Daha } \\
\text { sonra bunları arkadaşlarına sunarak } \\
\text { paylaşırlar. }\end{array}$ \\
\hline $\begin{array}{l}\text { Tecrübe etme- } \\
\text { Açıklama- } \\
\text { Uygulama }\end{array}$ & $\begin{array}{l}\text { Deney sırasında araştırmacı masaları } \\
\text { dolaşarak öğretmen adaylarının } \\
\text { takıldığı noktalarda onlara sorular } \\
\text { sorar, onların yorum yapmalarını } \\
\text { sağlar ve onlara gerekli açıklamalar } \\
\text { yaparak doğruya yönlendirir. } \\
\text { Araştırmacı, öğretmen adaylarına } \\
\text { bireysel olarak cevaplandıracakları } \\
\text { bir araştırma ödevi verir. Bir sonraki } \\
\text { derste bu ödevi sınıf ortamında } \\
\text { sunacaklarını hatırlatır. }\end{array}$ & $\begin{array}{l}\text { Öğretmen adayları Tahmin-Gözlem- } \\
\text { Açıklama yöntemine uygun olarak } \\
\text { geliştirilen deneyi yaparlar. } \\
\text { Deney kâğıdındaki sorular gönüllü } \\
\text { öğretmen adayları tarafından } \\
\text { cevaplanarak sınıfça tartış1lır. } \\
\text { Böylece deney "buz pisti" bağlamı } \\
\text { ile de ilişkilendirilmiş olur. }\end{array}$ \\
\hline $\begin{array}{l}\text { Uygulama- } \\
\text { Açıklama }\end{array}$ & $\begin{array}{l}\text { Öğretmen } \text { adayları tahtada soruları } \\
\text { çözerken } \\
\text { giderilmesi ve konunun daha iyi } \\
\text { anlaşılması için öğretmen adaylarına }\end{array}$ & $\begin{array}{l}\text { Öğretmen adayları itme-momentum } \\
\text { konusuyla ilgili sorulardan oluşmuş } \\
\text { testi bireysel olarak çözerler. Daha } \\
\text { sonra gönüllü ögretmen adayları }\end{array}$ \\
\hline
\end{tabular}




\begin{tabular}{|c|c|c|}
\hline & $\begin{array}{l}\text { sorular sorar. Onların daha detaylı } \\
\text { düşünmelerine yardımcı olur. Ayrıca } \\
\text { araştırmacı yanlış } \quad \text { yorumlanan } \\
\text { sorularda öğretmen } \\
\text { gerekli açılklamalar yapar. }\end{array}$ & soruları tahtada çözer. \\
\hline $\begin{array}{l}\text { Transfer etme- } \\
\text { İşbirliği- } \\
\text { Açıklama }\end{array}$ & $\begin{array}{l}\text { Öğretmen adaylarının } \\
\text { oldukları sunumlardaki eksik ve } \\
\text { yanlış noktalar araştırmacı tarafından } \\
\text { giderilir. } \\
\text { Ayrıca araştırmacı sınıf içinde } \\
\text { tartışma ortamı yaratarak konunun } \\
\text { roket hareketlerine transferini } \\
\text { gerçekleştirmeye çalışır. } \\
\text { Daha sonra araştırmacı roket } \\
\text { hareketlerinin daha iyi anlaşılmas } \\
\text { için "roket hareketleri" konusunu } \\
\text { anlatır ve ilgili örnekleri çözer. }\end{array}$ & $\begin{array}{l}\text { Bir önceki derste araştırmacı } \\
\text { tarafindan öğretmen adaylarına } \\
\text { verilen ödev, gönüllü öğretmen } \\
\text { adayları tarafindan sunulur. } \\
\text { Öğretmen adayları grupça } \\
\text { "momentum korunumunun günlük } \\
\text { hayat örnekleri ve açıklamaları" } \\
\text { başlıklı grup çalışmadaki soruları } \\
\text { cevaplayarak grupça sunarlar. }\end{array}$ \\
\hline
\end{tabular}

\section{Araştırmadan Elde Edilen Verilerin Analiz Yöntemi}

Tarama formundaki sorulara katılımcıların verdikleri cevaplar indirgemeler yapıldıktan sonra kritik cevaplar tespit edilmiştir. Ardından farklı zamanlarda, bu kritik cevaplara uygun kodlar belirlenmiş ve kod listesi oluşturulmuştur. Belirlenen bu kodlara göre, temalar oluşturulmuş ve kodlar uygun temaların altında sergilenmiştir. Ayrıca katılımcıların vermiş oldukları cevaplar arasından seçilen özgün cevaplar okuyucuya olduğu gibi sunulmuştur. Örneğin tarama formunun birinci sorusu olan "İtme, Momentum ve Çarpışmalar konularının işlendiği derslerin alış1k olduğunuz geleneksel öğretim yaklaşımından (genelde düz anlatımın yapıldığı diğer konularda olduğu gibi) farklı olarak işlenmesi hakkındaki düşünceleriniz nelerdir? Detaylıca aç1klayınız." sorusuna, K7, K10, K16, K18, K20, K22, K23, K24 ve K25 kodlu katılımciların, indirgemeler yapıldıktan sonraki "Geleneksel ögretim yaklaşımıyla uygulanan derslere göre daha akılda kalıcı." şeklindeki kritik cevapları "Öğrenme" temasının "Kalıcı" tematik koduna dâhil edilmiştir. Tarama formlarının analizinin ayrıntılı açılaması bulgular başlığı altında verilmiş olup, asıl uygulamada kullanılan tarama formu Ek 1'de sunulmuştur.

\section{Araştırmada Nitelik}

Pilot uygulama yapılmadan önce araştırmacı tarafından geliştirilen bütün ders planları, ders materyalleri ve veri toplama aracının görünüş ve kapsam geçerliğinin sağlanması için dört alan eğitimi ve anlaşılırlık açısından da Türkçe dil uzmanına kontrol ettirilmiş ve gerekli düzenlemeler yapılmıştır. Ek olarak uzmanların görüşleri doğrultusunda ders materyalleri ve veri toplama aracı sayfa düzeni ve okunabilirliği açısından tekrar düzenlenmiştir.

Materyallerin ve veri toplama aracının işlerliğinin belirlenmesi ve eksikliklerin giderilmesi yani geçerlik ve güvenirliğin artırılması için uzman görüşlerinin alınmasından sonra pilot çalışmalar yürütülmüştür. Böylece uygulamalar ve öğretmen adaylarının sorulara vermiş oldukları cevaplar incelenmiş ve gerekli ekleme çıkarmalar yapılarak süreç ve sorular düzenlenmiştir.

Geçerlilik ve güvenirlik nicel araştırmaların kullanılan niteliğini belirleyen gerekli kavramlarken nitel araştırmalarda farklı terimlere yer verilmektedir. Lincoln ve Guba'ya (1985) göre nitelikli bir araştırma inandırıcı, aktarılabilir, tutarlı ve teyit edilebilir olması gerekmektedir.

Uygulamalar ve veri toplama süreci başlamadan önce katılımcılara, araştırmacı tarafindan "bu uygulamaların ve verilerin dersleriniz için hiçbir değerlendirme niteliği taşımayacağı", "uygulamaların ve verilerin sadece araştırma amaçlı kullanılacă̆ı" ve "bazı demografik bilgileriniz dışında hiçbir verinin araştırmanın okurları ile paylaşılmayacağı" gibi 
bilgiler sunulmuştur. $\mathrm{Bu}$ bilgilendirmenin amacı katılımcıların uygulamalar ve veri toplama sürecinde rahat ve içten cevap vermelerini sağlayıp araştırmanın inandırıcılığını artırmaktır.

Ayrıca uygulamalar ve veri toplama süreci katılımcıların alışık olduğu ortamda yani derslerin de işlenmekte olduğu sınıfta gerçekleştirilerek araştırmanın inandırıcılığı artırılmaya çalışılmıştır.

Katılımcılar tarafından tarama formundaki sorulara verilen cevaplar araştırmanın inandırıcılık ve tutarlılığını artırmak amacıyla farklı zaman ve mekânlarda üç defa gerekli indirgemeler yapılıp kritik cevaplar tespit edilerek kod havuzları oluşturulmuş, bu kodlar da temalara ayrılmaya çalışılmıştır. Bu aşamaların geçerlik ve güvenirliği uzman görüşleri ile sağlanmıştır.

Araştırmanın geçerlik ve güvenirliğinin sağlanmasında bir diğer önemli nokta da araştırmacının pozisyonudur. Araştırmacı, aynı zamanda uygulama sınıflarının Genel Fizik I, Genel Fizik Laboratuvarı I, Genel Fizik II ve Genel Fizik Laboratuvarı II derslerinin yürütücü öğretim elemanı olarak bulunmaktadır. $\mathrm{Bu}$ durum katılımcıların alışık olduğu öğretim elemanıyla uygulamalarını gerçekleştirme olanağı sağlamış ve araştırmanın uzun süreli katılım eksikliği giderilmeye çalışılmıştır.

Aktarılabilirlik nitel araştırmalarda genelleme yerine kullanılan bir diğer kriterdir (Miles ve Huberman, 1994). Nitel araştırmalarda araştırma sonuçlarının genellemesinden ziyade benzer durumlara aktarılabilirliği söz konusudur (Yıldırım ve Şimşek, 2011). Bu araştırmada aktarılabilirliğin arttırılması adına araştırma sürecinde elde edilen veriler bulgular bölümünde okuyucuya yorum yapılmadan, verinin doğasına bağlı kalınarak, gerekli yerlerde temalar altında düzenlenerek sunulmuştur. Bu şekilde okuyucu araştırılan duruma ilişkin sonuçlara daha net bir şekilde ulaşacak ve kendi oluşturduğu araştırma durumlarına aktarma firsatını elde edecektir.

Araştırmacının elde ettiği sonuçların veri tarafindan desteklenmesi gerekmektedir (Miles ve Huberman, 1994). Bu, teyit edilebilirliğin göstergesidir. Bu araştırmada da katılımcıların doğrudan ifadelerine yer verilerek teyit edilebilirlik sağlanmaya çalışılmıştır.

\section{Araştırmada Etik}

Araştırmaya dâhil edilen katılımcıların uygulamalar ve veri toplama sürecinde toplanan verilerinin okuyucu ile paylaşımı konusunda rızaları alınmıştır. Ayrıca katılımcıların bazı demografik bilgilerinin de okuyucu ile paylaşılacağı açıkça belirtilerek onayları alınmış araştırmadan herhangi bir şekilde zarar görmeyecekleri belirtilmiştir (Cohen ve Manion, 1989; Drew, Hardman ve Hart, 1996). Uygulamalar ve veri toplama sürecinde araştırmacı ile katılımcılar arasında geçen bazı özel diyaloglar mahremiyet ve gizlilik ilkelerince araştırmaya yansıtılmamıştır. Bununla birlikte, araştırma etiği çerçevesinde uygulamalar ve veri toplama sürecine katılan öğretmen adayları (katılımc1lar) K1, K2, K3, ., K25 şeklinde kodlanarak isim gizliliği sağlanmıştır.

\section{Bulgular}

"Öğretmen adaylarının açıklama destekli REACT stratejisinin fizik öğretiminde kullanılması hakkındaki düşünceleri nelerdir?" araştırma problemini cevaplayabilmek için katılımcıların tarama formu sorularına vermiş oldukları cevaplarının analiz edilmesi gerekmektedir. Katılımcıların tarama formlarından elde edilen verilerden oluşturulan tema ve bu temalara ait kodlar Şekil 1'de sunulmuştur. 


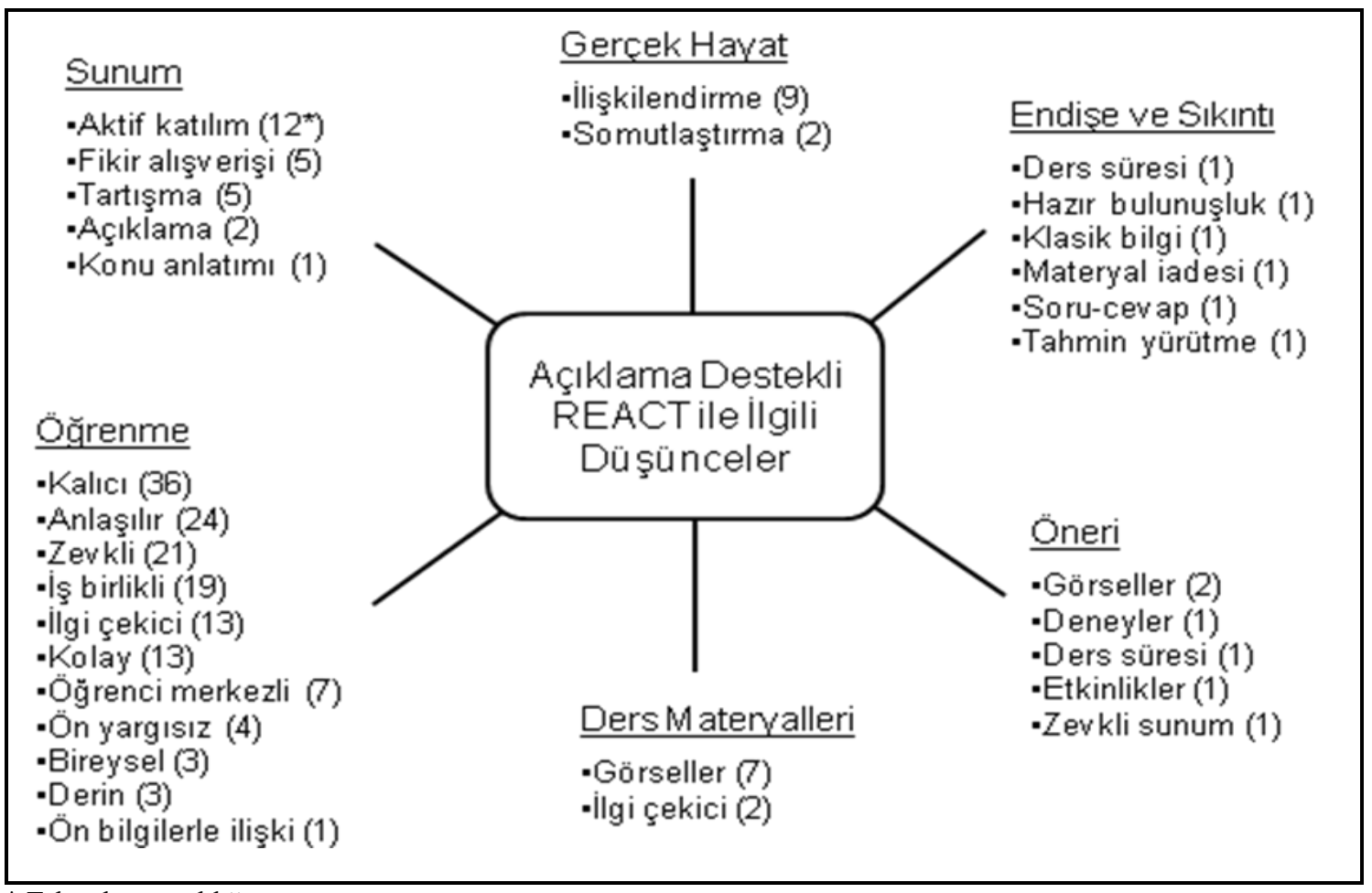

* Tekrarlanma sıklığ 1

Şekil 1. Katılımcıların Açıklama Destekli REACT Stratejisinin Fizik Öğretiminde Kullanılması Hakkındaki Düşünceleri

Şekil 1'e göre, katılımcıların açıklama destekli REACT stratejisinin fizik öğretiminde kullanılması hakkındaki düşünceleri 6 tema altında toplanmaktadır. Bu temalar, "Öğrenme", "Sunum", "Gerçek Hayat", "Endişe ve Sıkıntı", "Öneri” ve "Ders Materyalleri” şeklindedir.

Şekil 1 incelendiğinde, tarama formlarında katılımcılar, öğrenmenin kalıcı olduğunu 36 kez dile getirmişlerdir. Örneğin tarama formunun birinci sorusu olan "İtme, Momentum ve Çarpışmalar konularının işlendiği derslerin alışık olduğunuz geleneksel ögretim yaklaşımından (genelde düz anlatımın yapıldığı diğer konularda olduğu gibi) farklı olarak işlenmesi hakkındaki düşünceleriniz nelerdir? Detaylıca açıklayınız." sorusuna, K6, K7, K10, K16, K18, K20, K22, K23, K24 ve K25 kodlu katılımcılar "Geleneksel ögretim yaklaşımıyla anlatılan derslere göre daha akılda kalıcı." şeklinde cevap vermişlerdir. Tarama formunun dördüncü sorusu olan "Bundan sonra da fizik derslerinin bu şekilde işlenmesini ister miydiniz? Nedenleriyle açıklayınız." sorusuna da, K4, K7, K16, K19, K21, K22 ve K25 kodlu katılımc1lar "Kalıcıllı̆ artırdığ için isterim." şeklinde görüş belirtmişlerdir. Ayrıca katılımcılar öğrenmenin, anlaşılır bir biçimde gerçekleştiğini 24, zevkli bir şekilde gerçekleştiğini $21 \mathrm{kez}$ belirtmişlerdir. Örneğin, tarama formunun birinci sorusuna, K1, K4, K5, K6, K7, K9, K12, K14, K15, K17, K22, K23 ve K24 kodlu katılımcılar "Geleneksel ögretim yaklaşımına dayalı konu anlatımı sıkıcı ve anlaşılması zor oluyor. Bunda ise tam tersi." şeklinde cevap vermişlerdir. Tarama formu verilerine göre, katılımcılar tarafindan, iş birlikli öğrenmenin gerçekleştiği 19, öğrenmenin ilgi çekici ve kolay olduğu 13'er, öğrenci merkezli öğrenmenin bu strateji ile gerçekleştiği de yedi kez belirtilmiştir. Örneğin, tarama formunun ikinci sorusu olan "İtme, Momentum ve Çarpışmalar konularının işlendiği derslerde kullanılan bu yöntemin beğendiğiniz kısım(lar)1 nelerdir? Nedenleriyle açıklayınız." sorusuna K24 ve K25 kodlu katılımcılar "Poster hazırlama kısmını çok beğendim. Çünkü grup arkadaşlarımla bilgi alışverişi yaptık.” şeklinde cevap vermişlerdir. Açıklama destekli REACT stratejisine dayalı öğrenmenin ön yargıları giderdiğinin dört kez dile getirildiği tarama formunda, katılımcılar stratejinin, öğrenmeyi bireyselleştirdiğini ve derinleştirdiğini üçer, ön bilgilerle ilişkili olduğunu bir kez belirtmişleridir. Mesela, K6 kodlu 
katılımcı, tarama formunun dördüncü sorusuna "Ön yarglları kaldırdlğg için isterim." şeklinde, K11 kodlu katılımcı da, tarama formunun ikinci sorusuna "Geçmiş bilgilerin açı̆̆a çıkarılması." ş̧eklinde cevap vermiştir.

Şekil 1'e göre, "Sunum" teması incelendiğinde, katılımcılar, açıklama destekli REACT stratejisine dayalı derslerin sunumunda aktif katılımın sağlandığını belirtmişlerdir. Aktif katılım ile ilgili bu veri tarama formlarında $12 \mathrm{kez}$ tespit edilmiştir. Örneğin, tarama formunun dördüncü sorusuna, K1, K3, K4, K6, K7, K8, K14, K15 ve K22 kodlu katılımc1lar "Öğrenci aktif olduğu için isterim." şeklinde düşüncelerini belirtmişlerdir. Sunumlar esnasında kavramsal öğrenmenin daha iyi gerçekleşmesini sağlayan fikir alışverişlerinin ve tartışma ortamlarının yaratılması beşer kez dile getirilirken, etkili açıklamaların ve konu anlatımlarının katılımcılar tarafindan toplam üç kez belirtildiği görülmektedir. Örneğin, tarama formunun ikinci sorusuna, K3 ve K15 kodlu katılımeılar "Anlamadı̆̆ımız ve anlayamayacağımız kısımların açıklanması." şeklinde cevap vermişlerdir.

"Gerçek Hayat" teması incelendiğinde, Şekil 1'e göre, katılımcılar tarafindan, tarama formlarında, konunun gerçek hayatla ilişkilendirildiği dokuz, bilgilerin bu yolla somutlaştırıldığı ise iki kez dile getirilmiştir. Mesela, tarama formunun dördüncü sorusuna, K13 ve K21 kodlu katılımcılar cevaplarını "Копи gözle görülür, somut hale geldiği için isterim." şeklinde belirtmişlerdir.

Şekil 1'e göre, katılımcılar, açıklama destekli REACT stratejisi ile ilgili endişe ve sıkıntılarını da dile getirmişlerdir. Bu bağlamda katılımcıların, ders süreleri, hazır bulunuşluk, konu ile ilgili klasik bilgiler, derslerde kullanılan materyallerin geri toplanması, derslerin sorucevap ve tahmin yürütme kısımları konularında endişe ve sıkıntıları mevcuttur. Ancak "Endişe ve Sıkıntı" teması altında maddeler halinde sıralanan bu kodların frekansları bir olmuştur. Mesela, tarama formunun üçüncü sorusunun ilk aşaması olan "İtme, Momentum ve Çarpışmalar konularının işlendiği derslerde kullanılan bu yöntemin beğenmediğiniz kısım(lar)1 nelerdir? Nedenleriyle açıklayınız." sorusuna, K24 kodlu katılımcı "Derslerin uzun sürmesinden dolayı sikıliyorum." şeklinde, K17 kodlu katılımc1 "Korku ve sikıntı oluşturduğu için soru-cevap kısımları." şeklinde ve K21 kodlu katılımcı da "Öğrencilerin derse hazırlıksız gelişi dersleri olumsuz etkiliyor.” şeklinde cevap vermişlerdir.

Katılımcılar, tarama formlarında, açıklama destekli REACT stratejisi ile ilgili endişe ve sıkıntı yaşadıkları konulara paralel olarak bazı önerilerde bulunmuşlardır. Bunlar, uygulamalarda kullanılan görseller, deneyler, etkinlikler ile ders süreleri ve daha zevkli klasik bilgi sunumu konularında olmuştur. Ancak Şekil 1'e göre, tıpkı "Endişe ve Sıkıntı" temasını oluşturan kodların frekansları gibi "Öneri" temasını oluşturan bu kodlar da katılımcılar tarafından çok az sayıda, görseller kodu iki, diğer kodlar ise birer kez belirtilmiştir. Örneğin, tarama formunun üçüncü sorusunun ikinci aşaması olan "Derslerde kullanılan bu yöntemin beğenmediğiniz kısım(lar)1 için ne tür bir değişiklik yapılmasını önerirdiniz? Detaylıca açıklayınız." sorusuna, K24 kodlu katılıme1 "Dersler normal saatinden erken bitirilmeli." şeklinde ve K25 kodlu katılımcı da "Teorik bilgiler küçük kâğıtlarda eğlenceli notlar halinde sunulmall." şeklinde cevap vermiştir.

Son olarak, Şekil 1 incelendiğinde, katılımcılar, açıklama destekli REACT stratejisinin fizik öğretiminde kullanılması hakkındaki düşünceleri doğrultusunda uygulamalarda kullanılan ders materyalleri hakkında da görüş belirtmişlerdir. Tarama formu verilerine göre, katılımcılar tarafindan, ders materyallerinin görsellerle zenginleştirilmiş olması yedi ve materyallerin ilgi çekici olması da iki kez belirtilmiştir. Örneğin, tarama formunun ikinci sorusuna, K5, K7, K9, K15, K16, K18 ve K22 kodlu katılımcılar "Materyallerin görsellerle zenginleştirilmesi çok etkiliydi." ş̧eklinde cevap verirken, tarama formunun 4. sorusuna, K5 ve K24 kodlu katılımcilar "Ders materyalleri çok iyi ve ilgi çekici olduğu için isterim. " şeklinde görüşlerini belirmişlerdir.

\section{Tartışma}

Tarama formlarından elde edilen verilerin bir bütün olarak değerlendirildiği, bu verilerden elde edilen ortak tema ve bu temalara ait kodların yer aldığı Şekil 1'e göre, katılımcıların açıklama destekli REACT stratejisi ile ilgili düşünceleri genel olarak altı temada toplanmıştır. $\mathrm{Bu}$ 
temalardan katılımcıların açıklama destekli REACT stratejisini öğrenme ile ilişkilendirmeleri daha çok stratejinin öğrenme üzerindeki kalıcılığı ile ilgili olmuştur ki bu durum açıklama destekli REACT stratejisinin uygulandığı deney ve geleneksel öğretimin uygulandığı kontrol gruplarının gecikmiş kavram testi sonuçları ile desteklenmiştir. Gecikmiş testte, IBM SPSS v22' de yapılan bağımsız örneklemler t-testi sonuçlarına göre, deney grubu lehine anlamlı fark bulunmuştur ( $\left.X_{\text {deney }}=39,6 ; X_{\text {kontrol }}=28,5 ; t_{(48)}=2,599: p=0,012<0,05\right)$. Bununla beraber açıklama destekli REACT stratejisinin anlaşılır, zevkli, ilgi çekici ve kolay olmasının yanı sıra iş birlikli öğrenmeyi sağladığı için öğrenmeye pozitif etkileri olduğunu belirtmişlerdir. Nitekim literatürde de REACT stratejisinin pozitif öğrenme ortamının oluşturulmasında etkili olduğu belirtilmiştir (Coştu, 2009; Crawford, 2001). Grup çalışmaları ve iş birlikçi uygulamalar öğrencilerin ders başarısını ve düşünme becerisini geliştirir (Kovac, 1999; Özmen ve Yıldırım, 2005; Sisovic ve Bojovic, 2000). Bu araştırma kapsamında öğretmen adaylarının grupça yaptıkları çalışmalar sonucunda kimlik ve önemli olma hissi gibi sosyal duygularının geliştirilmesi, bu durumun sebebi olarak görülebilir (Davidson, 1990).

Şekil 1'e göre, katılımcıların açıklama destekli REACT stratejisine uygun hazırlanan ders materyalleri hakkındaki düşünceleri ise materyallerin görsel ve ilgi çekici olduğudur. Ayrıca açıklama destekli REACT stratejisinde kullanılan materyallerin gerçek hayattan örnekleri kapsıyor olması konunun somutlaştırılmasına da yardımcı olmuştur (Ültay ve diğerleri, 2014). Bilgilerin günlük yaşamla ilişkilendirilmesi öğretimin kalıcılığını da olumlu yönde etkilemektedir (Ültay ve Çalık, 2012). Bununla beraber literatürde de günlük yaşamla ilişkilendirilen derslerin öğretmen adayları tarafından daha fazla ilgi gördüğüne dair sonuçlar elde edilmiştir (Aktaş, 2013; Bulte, Westbroek, de Jong ve Pilot, 2006; Campbell ve Lubben, 2000).

Şekil 1'e göre, açıklama destekli REACT stratejisinin öğretmen adaylarının aktif katılımını sağlaması, onların fikir alışverişi yapmalarına yardımcı olmuş ve dolayısıyla tartışmaya uygun bir ortam hazırlanmıştır. Bu noktalar, stratejinin, ders sunumu ile ilgili olumlu yönleridir. Saka'ya (2011) göre, REACT stratejisine ve bağlam temelli yaklaşıma uygun hazırlanan dersler öğrenci merkezli oldukları için öğrencilerin öğrenmelerini ve fizik dersine karşı tutumlarını olumlu yönde etkilemektedir. Nitekim katılımcıların açıklama destekli REACT stratejisi ile ilgili sundukları öneriler de yine öğrenci merkezli aktivitelerin artırılması ile ilgilidir. Örneğin katılımcılar deneyler ve etkinliklerin sayısının artırılmasını önermişlerdir.

Açıklama destekli REACT stratejisi ile ilgili tüm bu olumlu noktalara rağmen, bazı katılımcılar bazı konularda hala endişe ve sıkıntı duyduklarını dile getirmişlerdir. Örneğin öğretim sürecinde yer alan soru-cevap ve tahmin yürütme aşamalarında katılımcılar endişe ve sıkıntı duymuşlardır. Bunun sebebi de bazı öğretmen adaylarının aktif olarak derse katılmak istememeleri olabilir. Çünkü bundan önceki öğretim hayatlarında bilgiyi hazır almaya alışkın olduklarından, aktif öğrenme sürecine alışmak ve adapte olmak zor gelmiş olabilir. Ayrıca sürekli heyecan, aktiflik ve araştırma üzerine kurgulanan bir öğretim onları yormuş veya sıkmış da olabilir. Bu durum aktif öğrenmeye dayalı yöntem ve tekniklerin kullanıldığı öğrenme ortamlarına karşı bir süre sonra öğretmen adaylarının direnç göstermelerine neden olabilir (Özsevgeç, 2007).

Açıklama destekli REACT stratejisi ile birlikte, öğretmen adayları REACT stratejisindeki gibi sınav kaygısına düşerek, öğretmenin düz anlatım yapacağı bölüm beklentisine kapılmamışlardır (N. Ültay, 2012). Nitekim açıklama destekli REACT stratejisi ile görüşlerin sorgulandığı tarama formunda da katılımcılar bu konuyla ilgili olumsuz bir görüş bildirmemişlerdir. Açıklama destekli REACT stratejisinin bütün aşamalarında, katılımcıların gerek duyması halinde, araştırmacı açıklamalar yaparak onların konuyu daha net anlamalarına yardımcı olmuş olabilir. Açıklama ilkesinde katılımcıların alışkın oldukları şekilde bilginin açıklanması kendilerini güvende hissetmelerine yol açmış olabilir. Ayrıca kullanılan günlük yaşamla ilişkili materyal ve bağlamlar katılımcıların ilgisini konuya çekmiş, yapılan açıklamalar ise konuyu daha iyi anlamalarına yardımcı olmuş olabilir.

REACT stratejisinin bütün aşamaları isminde yazılan sıra ile değil, döngüsel olarak kullanılmaktadır (Çatlıoğlu, 2010; Navarra, 2006). Bu sebeple eklenen "Açılama” ilkesi de 
araştırmaya ayrı bir aşama olarak değil, bütün aşamalarına gerekli yerlerde kullanılmak üzere döngüsel olarak eklenmiştir. Bununla birlikte, "Açıklama" ilkesi teorik bilgilerin düz anlatımla verilmesini gerektirmez. Farklı öğretim yöntem ve teknikleriyle zenginleştirilerek katılımcıların sıkılması önlenebilir (Özmen, 2002). Nitekim bu araştırmada da çarpışmalar konusu anlatılırken açıklama ilkesinde simülasyonlar kullanılmıştır. Bu sayede açıklanan teorik bilgiler görselleştirilerek somutlaştırılmıştır. Açıklama destekli REACT stratejisine yönelik katılımcıların görüşleri dikkate alındığında, stratejinin konunun somutlaştırılmasında etkili olduğunu söylemeleri buna örnektir. Ayrıca katılımcıların, tarama formunun (Ek-1) üçüncü sorusunun ikinci bölümündeki soru için, konu anlatımlarını küçük eğlenceli notlar şeklinde istemeleri, konu hakkındaki açıklamaları düz anlatım olarak istemediklerinin göstergesidir. $\mathrm{Bu}$ sebeple açıklama ilkesi farklı öğretim yöntem ve teknikleriyle zenginleştirilerek kullanılabilir.

\section{Sonuçlar ve Öneriler}

Açıklama destekli REACT stratejisinde günlük yaşamla ilişkili örnek ve bağlamların kullanılması katılımcıların ilgilerini canlı tutmuş ve açıklama destekli REACT stratejisine dayalı uygulamalar hakkında katılımcılar olumlu yönde görüşler bildirmişlerdir. Örneğin günlük yaşamla ilişkili örnek ve bağlamlar akılda kalıcılığı sağladığı gibi, ayrıca bu sayede derslerin daha zevkli, anlaşılır ve ilgi çekici olduğu sonucuna ulaşılmıştır. Açıklama destekli REACT stratejisinde kullanılan günlük yaşama dayalı örnek ve seçilen bağlamlar katılımcıların ilgi ve motivasyonlarıyla direkt ilişkili olduğundan, seçilen örnek ve bağlamların katılımcıların ilgisini çekecek ve tamamına hitap edecek şekilde belirlenmesi önerilir. Açıklama destekli REACT stratejisine dayalı uygulamalar öğretmen adaylarının aktif katılımını sağlayarak onların motivasyonlarını artırmış olduğu düşünülmektedir. Katılımcıların açıklama destekli REACT stratejisi ile ilgili görüşleri dikkate alındığında, kendilerinin derslere en çok aktif olarak katılmalarını beğendikleri ve bu konuda önerilerde bulundukları için, açıklama destekli REACT stratejisine dayalı yapılacak uygulamalarda deney, etkinlik ve onların aktif katılımını sağlayacak her tür aktiviteye özellikle yer verilmesi önerilmektedir.

Katılımcıların açıklama destekli REACT stratejisine dayalı uygulamalarla ilgili olarak, konu ile ilgili teorik bilgilerin sunulduğu bir açıklamaya ihtiyaç duymamaları veya bu konuda olumsuz görüş bildirmemeleri, REACT stratejisinde "Açıklama" ilkesinin olmamasıyla ilgili ortaya çıkan sıkıntının giderildiğini göstermektedir. Bununla birlikte açıklama destekli REACT stratejisinde döngüsel olarak kullanılan "Açıklama"ların etkili olduğu katılımcıların görüşlerinden anlaşılmaktadır. Bu da REACT stratejisine "Açıklama" ilkesinin eklenmesinin olumlu sonuç verdiğini göstermektedir. Bu sebeple katılımcıların açıklama destekli REACT stratejisi ile ilgili görüşleri dikkate alındığında, konu ile ilgili yapılacak açıklamaların düz anlatımdan ziyade farklı öğretim yöntem ve teknikleriyle zenginleştirilmesi (bu araştırmada kullanılan simülasyonlar gibi) önerilmektedir.

Ayrıca, tutumun kısa sürede değişmesinin veya değiştirilmesinin zor olduğu bilinmektedir (Karamustafaoğlu, 2003; Sağlam, 2005). Bu sebeple bu araştırmada tutum yerine öğretmen adaylarının açıklama destekli REACT stratejisinin fizik öğretiminde kullanılması hakkındaki düşünceleri araştırılmıştır. Açıklama destekli REACT stratejisi ile ilgili katılımcıların olumlu düşünceleri, daha uzun süreli yapılan araştırmalarda tutumun da değişebileceğini düşündürmektedir. Bu bağlamda, açıklama destekli REACT stratejisinin kullanıldığı daha uzun süreli araştırmalarda fizik dersine karşı olan tutum da araştırılabilir.

\section{Kaynaklar}

Acar, B. ve Yaman, M. (2011). Bağlam temelli öğrenmenin öğrencilerin ilgi ve bilgi düzeylerine etkisi. Hacettepe Üniversitesi Eğitim Fakültesi Dergisi, 40, 1-10.

Akdeniz, A. R. ve Akbulut, Ö. E. (2010). Fizik öğretmen adaylarının geliştirdikleri yapılandırmacı öğretim etkinliklerinin değerlendirilmesi. Necatibey Eğitim Fakültesi Elektronik Fen ve Matematik Eğitimi Dergisi, 4(1), 50-63. 
Aktamış, H. A., Ergin, Ö. ve Akpınar, E. (2002). Yapısalcı kurama örnek bir uygulama. V. Ulusal Fen Bilimleri ve Matematik Eğitimi Kongresi içinde (s. 239-245). Ankara: Ortadoğu Teknik Üniversitesi, Eğitim Fakültesi.

Aktaş, L. (2013). Maddenin tanecikli yapısı ve ısı konusunda REACT öğretim stratejisine yönelik geliştirilen bilgisayar destekli öğretim materyalinin öğrenci başarısına etkisi (Yayımlanmamış yüksek lisans tezi), Karadeniz Teknik Üniversitesi, Trabzon.

Ay, S. (2008). Lise seviyesinde öğrencilerin günlük yaşam olaylarını açıklama düzeyi ve buna kimya bilgilerinin etkisi (Yayımlanmamış yüksek lisans tezi). Marmara Üniversitesi, İstanbul.

Ayvacı, H. Ş. (2010). Fizik öğretmenlerinin bağlam temelli yaklaşım hakkındaki görüşleri. Dicle Üniversitesi Ziya Gökalp Ĕ̈itim Fakültesi Dergisi, 15, 42-51.

Ayvacı, H. Ş., Ültay, E. ve Mert, Y. (2013). 9. sınıf fizik kitabında yer alan bağlamların değerlendirilmesi. Necatibey Ĕgitim Fakültesi Elektronik Fen ve Matematik Eğitimi Dergisi, 7(1), 242-263.

Azuma, T. ve Nagao, K. (2008). An inquiry into the reproduction of physics-phobic children by physics-phobic teachers. arXiv:0803.3167v2 [physics.ed-ph], 1-12.

Balc1, A. (2011). Araştırma Sosyal Bilimlerde Araştırma (Gözden geçirilmiş ve geliştirilmiş 9. bask1). Ankara: PegemA Yayıncılık.

Basir, M. A., Alinaghizadeh, M. R. ve Mohammedpour, H. (2008). A suggestion for improving students' abilities to deal with daily real-life problems. Physics Education, 43(4), 407411.

Berns, R. G. ve Erickson, P. M. (2001). Contextual teaching and learning: Preparing students for the new economy. The Highlight Zone Research Work, 5, 1-8.

Bulte, A. M. W., Westbroek, H. B., de Jong, O. ve Pilot, A. (2006). A research approach to designing chemistry education using authentic practices as contexts. International Journal of Science Education, 28(9), 1063-1086.

Büyüköztürk, Ş., Kılıç Çakmak, E., Akgün, Ö. E., Karadeniz, Ş. ve Demirel, F. (2012). Bilimsel araştırma yöntemleri (Geliştirilmiş 12. Baskı). Ankara: PegemA Yayıncılık.

Campbell, B. ve Lubben, F. (2000). Learning science through contexts: Helping pupils make sense of everyday situations. International Journal of Science Education, 22(3), 239-252.

Choi, J. S. ve Song, J. (1996). Students' preferences for different contexts for learning science. Research in Science Education, 26(3), 341-352.

Cohen, L. ve Manion, L. (1989). Research methods in education (4th Ed.). New York: Routledge.

Colburn, A. (2000). Constructivism: Science education's "Grand Unifying Theory". Clearing House, 74(1), 9-12.

CORD, (1999a). Teaching mathematics contextually. Waco, Texas, USA: CORD Communications, Inc.

CORD, (1999b). Teaching science contextually. Waco, Texas, USA: CORD Communications, Inc.

Coştu, S. (2009). Matematik öğretiminde bağlamsal öğrenme ve öğretmen yaklaşımına tasarlanan öğrenme ortamlarında öğretmen deneyimleri (Yayımlanmamış yüksek lisans tezi). Karadeniz Teknik Üniversitesi, Trabzon.

Crawford, M. L. (2001). Teaching contextually: Research, rationale, and techniques for improving student motivation and achievement in mathematics and science. Waco, Texas: CCI Publishing.

Çatlığlu, H. (2010). Matematik öğretmeni adaylarıyla bağlamsal öğrenme ve öğretme deneyiminin değerlendirilmesi (Yayınlanmamış doktora tezi). Karadeniz Teknik Üniversitesi, Trabzon

Davidson, N. (1990). Cooperative learning in mathematics: A handbook for teachers. Menlo Park, CA: Addison-Wesley Publishing Company, Inc. 
Demircioğlu, H., Demircioğlu, G. ve Çalık, M. (2009). Investigating effectiveness of storylines embedded within context based approach: A case for the periodic table. Chemistry Education Research and Practice, 10, 241-249.

Drew, C. J., Hardman, M. L. ve Hart, A. W. (1996). Designing and conducting research: Inquiry in education and social science (2nd ed.). Boston: Allyn and Bacon.

Edwards, C. (2000). Physics learning through a telecommunications context. Physics Education, $35(4), 240-244$.

Finkelstein, N. (2005). Learning physics in context: A study of student learning about electricity and magnetism. International Journal of Science Education, 27(10), 1187-1209.

Gilbert, J. K. (2006). On the nature of "context" in chemical education. International Journal of Science Education, 28(9), 957-976.

Glynn, S. M. ve T. R. Koballa, Jr. (2005). The contextual teaching and learning instructional approach. R. E. Yager (Yay. haz.), Exemplary science: Best practices in professional development içinde (ss. 75-84). Arlington, VA: NSTA press.

Harrison, A. G. ve Treagust, D. F. (2001). Conceptual change using multiple interpretive perspectives: Two case studies in secondary school chemistry. Instructional Science, 29, 45-85.

Hewson, M. G. ve Hewson, P. W. (2003). Effect of instruction using students' prior knowledge and conceptual change strategies on science learning. Journal of Research in Science Teaching, 40, 86-98.

Hewson, P. W. (1992). Conceptual change in science teaching and teacher education. National Center for Educational Research, Documentation, and Assessment, Madrid, Spain.

Imel, S. (2000). Contextual learning in adult education. Practice Application Brief. 12.

Karamustafaoğlu, S. (2003). "Maddenin iç yapısına yolculuk" ünitesi ile ilgili basit araçgereçlere dayall rehber materyal geliştirilmesi ve ögretim sürecindeki etkililiği (Yayımlanmamış yüksek lisans tezi). Karadeniz Teknik Üniversitesi, Trabzon.

Kovac, J. (1999). Student active learning methods in general chemistry. Journal of Chemical Education, 76(1), 120-124.

Lincoln, Y. S. ve Guba, E. G. (1985). Naturalistic inquiry. California: Sage Publications, Inc.

Lynch, R. L. ve Padilla, M. J. (2000). Contextual teaching and learning in preservice teacher education. National Conference on Teacher Quality, January 10, Washington DC.

Miles, M. B. ve Huberman, A. M. (1994). Qualitative data analysis (2nd ed.). California: Sage Publications, Inc.

Navarra, A. (2006). Achieving pedagogical equity in the classroom. CORD Publishing.

Özmen, H. (2002). Fen öğretiminde öğrenme teorileri ve teknoloji destekli yapılandırmac1 (constructivist) öğrenme. The Turkish Online Journal of Educational Technology, 3(1), 100-111.

Özmen, H. ve Yıldırım, N. (2005). Çalışma yapraklarının öğrenci başarısına etkisi: Asit ve bazlar örneği. Türk Fen Eğitimi Dergisi, 2(2), 124-143.

Özsevgeç, T. (2006). Kuvvet ve hareket ünitesine yönelik 5E modeline göre geliştirilen öğrenci rehber materyalinin etkililiğinin değerlendirilmesi. Türk Fen Ĕgitimi Dergisi, 3(2), 36-48.

Özsevgeç, T. (2007). Illkögretim 5.sinuf kuvvet ve hareket ünitesine yönelik 5E modeline göre geliştirilen rehber materyallerin etkililiklerinin belirlenmesi (Yayımlanmamış doktora tezi). Karadeniz Teknik Üniversitesi, Trabzon.

Pilot, A. ve Bulte, A. M. W. (2006). Why do you "need to know"? Context-based education. International Journal of Science Education, 28(9), 953-956.

Rayner, A. (2005). Reflections on context-based science teaching: A case study of physics for students of physiotherapy. UniServe Science Blended Learning Symposium Proceedings, $169-172$.

Sağlam, M. (2005). Işık ve ses ünitesi konusunda $5 E$ modeline uygun rehber materyal geliştirilmesi ve etkililiğinin araştırılması (Yayımlanmamış doktora tezi). Karadeniz Teknik Üniversitesi, Trabzon. 
Saka, A. (2006). Fen bilgisi ögretmen adaylarının genetik konusundaki kavram yanılgılarının giderilmesinde 5E modeli'nin etkisi (Yayımlanmamış doktora tezi). Karadeniz Teknik Üniversitesi, Trabzon.

Saka, A. Z. (2011). Investigation of student-centered teaching applications of physics student teachers. Eurasian Journal of Physics and Chemistry Education, Jan (Special Issue), 5158.

Sharma, B. K. (2004). Can we make physics popular? Proceeding of Second Annual Conference and National Conference On "How To Make Physics Popular?" Jaipur, India, 11-13.

Sisovic, D. ve Bojovic, S. (2000). Approaching the concepts of acids and bases by cooperative learning. Chemistry Education Research and Practice, 1(2), 263-275.

Souders, J. (1999). Contextually based learning: Fad or proven practice. American Youth Policy Forum, July 9, Capitol, Hill.

Stolk, M. J., Bulte, A. M. W., de Jong, O. ve Pilot, A. (2009a). Towards a framework for a professional development programme: Empowering teachers for context-based chemistry education. Chemistry Education Research and Practice, 10, 164-175.

Stolk, M. J., Bulte, A. M. W., de Jong, O. ve Pilot, A. (2009b). Strategies for a professional development programme: Empowering teachers for context-based chemistry education. Chemistry Education Research and Practice, 10, 154-163.

Tekbıyık, A. (2010). Bağlam temelli yaklaşımla ortaöğretim 9.sınıf enerji ünitesine yönelik $5 E$ modeline uygun ders materyallerinin geliştirilmesi (Yayımlanmamış doktora tezi). Karadeniz Teknik Üniversitesi, Trabzon.

Ültay, E. (2012). Implementing react strategy in a context-based physics class: Impulse and momentum example. Energy Education Science and Technology Part B: Social and Educational Studies, 4(1), 233-240.

Ültay, E. (2013). A thematic review of context-based physics studies. Saarbrücken, Germany: LAP Lambert Academic Publishing.

Ültay, E. (2017). Examination of context-based problem-solving abilities of pre-service physics teachers. Journal of Baltic Science Education, 16(1), 113-122.

Ültay, E. ve Ültay, N. (2014). Context-based physics studies: A thematic review of the literature. Hacettepe University Journal of Education, 29(3), 197-219.

Ültay, N. (2012). Asit ve baz konusuyla ilgili REACT stratejisine ve $5 E$ modeline göre etkinliklerin geliştirilmesi, uygulanmasi ve karşilaştirilmasi (Yayınlammamış doktora tezi). Karadeniz Teknik Üniversitesi, Trabzon.

Ültay, N. ve Çalık, M. (2012). A thematic review of studies into the effectiveness of contextbased chemistry curricula. Journal of Science Education and Technology, 21, 686-701.

Ültay, N., Durukan, Ü. G. ve Ültay, E. (2014, May). Determination of student teachers' views about REACT strategy. International Conference on Education in Mathematics, Science and Technology (ICEMST2014), Necmettin Erbakan University, Konya.

Van Hook, S. J. ve Huziak-Clark, T. L. (2007). Tip-to-tail: Developing a conceptual model of magnetism with kindergartners using inquiry-based instruction. Journal of Elementary Science Education, 19(2), 45-58.

Whitelegg, E. (1996). The supported learning in physics project. Physics Education, 31, 291296.

Whitelegg, E. ve Edwards, C. (2001). Beyond the laboratory: Learning physics in real life contexts. R. Duit (Yay. haz.), Research in science education: Past, present and future içinde (s. 337-342). Dordrect, Netherlands: Kluwer Academic Publishers.

Wierstra, R. F. A. (1984). A study on classroom environment and on cognitive and affective outcomes of the PLON-curriculum. Studies in Educational Evaluation, 10, 273-282.

Wilkinson, J. W. (1999b). The contextual approach to teaching physics. Australian Science Teachers Journal, 45(4).

Yaman, M., Dervişoğlu, S. ve Soran, H. (2004). Ortaöğretim öğrencilerinin derslere ilgilerinin belirlenmesi. Hacettepe Üniversitesi Eğitim Fakültesi Dergisi, 27, 232-240. 
Yıldırım, A. ve Şimşek, H. (2011). Sosyal bilimlerde nitel araştırma yöntemi (8.baskı). Ankara: Seçkin Yayıncılık.

\section{Extended Abstract}

\section{Introduction}

The context-based learning approach, which foresees students to use familiar contexts to associate new knowledge with the experiences of their daily lives, is based primarily on constructivist learning approach. The creation of a need-to-know basis is the cornerstone of the context-based learning approach and is also very meaningful in terms of teaching. Learning will be meaningful and permanent as students learn by doing. In this way, as the compatibility of the information with each other will increase, the interest and motivation of the students will also increase.

One of the strategies used in learning environments to fulfill the objectives that the context-based learning approach aims to achieve is the REACT strategy. Some studies in the literature have pointed out the problems encountered during the implementation of the REACT strategy and the need to develop the REACT strategy. The common point in these studies is the problems arising from the lack of the "explanation" principle in the REACT strategy.

Making explanations help students to change insufficient preliminary thoughts with more accurate ones because students often have difficulty finding new ways of thinking without the help of the teacher. In this sense, it is thought that during the education and training, especially the extended version of the REACT strategy in which the lack of explanation principle is experienced, the explanation-assisted REACT strategy should be tried in the teaching environments.

It is noteworthy that the subject of impulse, momentum and collisions is very little studied when considering the physics education studies on which the context-based learning approach is used. In fact, the subject of impulse, momentum and collisions is a subject that students are familiar with in their daily lives. In this context, it is important teaching this subject within the context of everyday life and implementing the explanation-assisted REACT strategy which is an extended version of the existing REACT strategy as suggested in some studies that students and teacher candidates have a lot of alternative concepts about impulse, momentum and collisions. From this, the main aim of this study was to examine the science teachers' ideas about the use of the explanation-assisted REACT strategy in physics teaching.

The study was suited to the case study method since it was attempted to determine the opinions of the teacher candidates about the explanation-assisted REACT strategy in the study. The case method is a method in which one or more events, the environment, the program, the social group, or other interrelated systems are examined in depth. In this study, it was used to deeply consider the thoughts of a group about a particular subject. The sample of this research was consisted of 25 teacher candidates who were studying in the first grade in Giresun University Faculty of Education Science Education Department.

In this study, a questionnaire was used as a data collection tool. The form consisting of open-ended questions aimed to acquire in-depth information about the teaching strategy from the teacher candidates.

Before examining teacher candidates' opinions about the explanation-assisted REACT strategy, they were taught impulse, momentum and collisions subject in accordance with the explanation-assisted REACT strategy over a 10 -hour course $(10 * 50$ minutes $=500$ minutes $)$ in General Physics I and General Physics Laboratory I courses.

\section{Findings}

The opinions of the science teacher candidates about the strategy were grouped under six themes. These themes were stated as "learning", "presentation", "real life", "anxiety and trouble","suggestion" and "course materials". 
When Figure 1 in which the participants' opinions about the explanation-assisted REACT strategy were presented was considered, the participants stated that learning was permanent 36 times in the questionnaire. According to the questionnaire data, the participants stated that "the cooperative learning takes place in the strategy" 19 times, that "the learning is interesting and easy" 13 times, and that "the student centered learner was achieved in this strategy" seven times. In the questionnaire data in which it was indicated that "the explanationassisted REACT strategy eliminated prejudices" four times, the participants stated that "learning was individualized and was made deepened by the strategy" three times, "the strategy was related to preliminary knowledge" once.

When the theme of "presentation" was examined, the participants indicated that they were actively involved in the presentation of lessons based on the explanation-assisted REACT strategy. This data on active participation was found 12 times in the questionnaire data. During the presentations, it was seen that the creation of the ideas and discussion environments that made the conceptual learning worked better was stated for five times, the effective explanations and the narration of the subjects were indicated by the participants three times in total.

When the "real life" theme was examined, it was mentioned by the participants in the questionnaire data that "the subject is related to the real life" nine times, and "the information is embodied in this way" two times.

Participants also expressed their anxiety and distresses with the explanation-assisted REACT strategy. In this context, participants had anxiety and distresses about the class hours, readiness, content knowledge about the subject, recall of the materials used in the lessons, and question-answer parts of the lessons. However, the frequencies of these codes, which were listed as "Anxiety and Distress", were first participants had made some suggestions according to the codes under this theme. In addition, it had been stated seven times that the course materials had been enriched via the visuals by the participants. It had also been mentioned twice that the materials were interesting.

\section{Discussion}

Participants mostly associated the explanation-assisted REACT strategy with the permanency of the strategy over learning. However, they pointed out that the explanation-assisted REACT strategy was positively affected learning because the strategy was understandable, enjoyable, engaging and easy to learn, as well as it was provided cooperative learning. Indeed, it is stated in the literature that the REACT strategy is effective in establishing a positive learning environment.

The participants' thoughts on the course materials prepared in accordance with the explanation-assisted REACT strategy were visual and interesting. In addition, the fact that the materials used in the explanation-assisted REACT strategy included real-life examples also helped to make the subject concrete. Associating information with everyday life also affected the permanence of teaching positively. In the literature, however, the results showed that the lessons related to daily life were attracted more attention by teacher candidates.

Together with the explanation-assisted REACT strategy, teacher candidates had not been exposed to the test anxiety as in the REACT strategy in which they were waiting for the presentation of the content knowledge. As a matter of fact, participants did not give any negative opinion on this issue in the questionnaire form. In all stages of the explanation-assisted REACT strategy, if the participants needed it, the researcher could have made some explanations for the clarity and helped them understood the subject better. Making explanations, as the participants were accustomed to in before lessons, may have caused them to feel safe. In addition, the materials and contexts associated with everyday life used attracted the interest of the participants and the explanations could have helped to understand better the subject.

\section{Conclusions and Suggestions}

Participants commented positively about the use of contexts related to everyday life in the explanation-assisted REACT strategy and on the implementation of the strategy. Since 
examples and selected contexts based on everyday life used in the explanation-assisted REACT strategy were directly related to the interests and motivations of the participants, it is suggested that the selected contexts should be interesting and appealing to the participants.

The fact that the participants did not need an explanation of the theoretical information on the subject or not give the negative feedbacks on this issue showed that the difficulty with regard to the lack of the "explanation" principle in the REACT strategy has been overcome. However, it is evident from the views of participants that the "explanations" used cyclically in the explanation-assisted REACT strategy were effective. This shows that the addition of the "explanation" principle to the REACT strategy had a positive effect. For this reason, it is suggested that the explanations to be made about the subject should be enriched by a variety of different teaching techniques. It is also known that it is difficult to change the attitude in a short time. For this reason, instead of attitudes in this study, teacher candidates' thoughts were searched about the strategy. Participants' positive thoughts on the explanation-assisted REACT strategy suggest that attitudes may change in longer-term studies. In this context, the attitude towards the physics course can also be investigated in longer studies using the explanationassisted REACT strategy.

\section{EK 1. Tarama Formu}

\section{TARAMA FORMU}

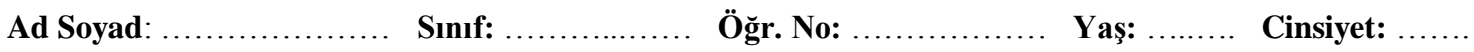

Açıklama: Bu tarama formu sizin İtme, Momentum ve Çarpışmalar konularının işlendiği derslerde kullanılan yöntem, öğrenme yaklaşımı, etkinlikler, materyaller ve dersin işlenişi hakkında görüş, öneri ve eleştirilerinizi almak amacıyla hazırlanmıştır. Lütfen samimi cevaplar veriniz.

Öğr. Gör. Eser ÜLTAY

- İtme, Momentum ve Çarpışmalar konularının işlendiği derslerin alışık olduğunuz geleneksel öğretim yaklaşımından (genelde düz anlatımın yapıldığı diğer konularda olduğu gibi) farklı olarak (bağlam temelli öğrenme yaklaşımıyla) işlenmesi hakkındaki düşünceleriniz nelerdir? Detaylıca açıklayınız.

- İtme, Momentum ve Çarpışmalar konularının işlendiği derslerde kullanılan bu yöntemin beğendiğiniz kısım(lar)ı nelerdir? Nedenleriyle açıklayınız.

- İtme, Momentum ve Çarpışmalar konularının işlendiği derslerde kullanılan bu yöntemin beğenmediğiniz kısım(lar)1 nelerdir? Nedenleriyle açıklayınız.

- Derslerde kullanılan bu yöntemin beğenmediğiniz kısım(lar)1 için ne tür bir değişiklik yapılmasını önerirdiniz? Detaylıca açıklayınız. 
Ültay ve Alev

- Bundan sonra da fizik derslerinin bu şekilde işlenmesini ister miydiniz? Nedenleriyle açıklayınız.

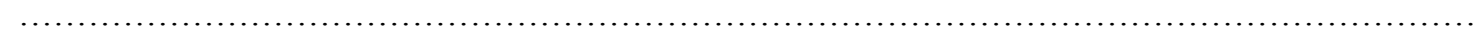

